\title{
Ruminal methanogens and bacteria populations in sheep are modified by a tropical environment
}

\author{
Moufida Rira ${ }^{a, 1}$, Diego P. Morgavi ${ }^{a}$, Milka Popova ${ }^{a}$, Carine Marie-Magdeleine ${ }^{b}$, \\ Tatiana Silou-Etienne $^{\mathrm{b}}$, Harry Archimède ${ }^{\mathrm{b}}$, Michel Doreau ${ }^{\mathrm{a}, *}$ \\ a INRA, VetAgro Sup, UMR1213 Herbivores, F-63122 Saint-Genès-Champanelle, France \\ b INRA, UR143 URZ, 97170 Petit-Bourg, Guadeloupe, France
}

\section{A R T I C L E I N F O}

\section{Article history:}

Received 11 May 2016

Received in revised form 13 July 2016

Accepted 9 August 2016

\section{Keywords:}

Rumen microbiota

Volatile fatty acids

Temperate $v$ s tropical site

Sheep breed

Forage

Methane

\begin{abstract}
A B S T R A C T
Microbial fermentation of carbohydrates in the rumen is largely responsible for the emission of methane by ruminants. Ruminants fed tropical forages usually produce more enteric methane than ruminants fed temperate forages. The relative influence of forage type, breed and temperate $v$ s tropical environment on rumen microbial populations is not known. This experiment aimed to separate these effects. We designed two parallel experiments in sheep in two sites: temperate (France) and tropical (French West Indies), using in each site two breeds, Texel (temperate origin), and Blackbelly (tropical origin) fed the same temperate forages ( $\mathrm{C} 3$ carbon fixation, permanent grasslands of high and low quality) and tropical forages (C4 carbon fixation, permanent grasslands of high and low quality). We determined diet digestibility, ruminal end-products of fermentation and microbial groups: total protozoa, methanogens and bacteria, and selected fibrolytic bacteria. Dry matter digestibility coefficient was higher in tropical site $(612 v s 580 \mathrm{~g} / \mathrm{kg}$ on average, $P=0.004)$ but no difference was observed between C3 and C4 forages. There was no effect of site on total VFA concentration, but the acetate:propionate ratio was higher for the tropical site (4.30 vs 3.93 on average, $P=0.007$ ). The acetate:propionate ratio was also affected by forage type with higher values for $\mathrm{C} 3$ than $C 4$ forage ( 4.24 vs 3.99 on average, $P=0.03$ ). Concentration of total rumen bacteria and methanogens was determined by qPCR targeting, respectively, the rrs (16S ribosomal RNA subunit) and mcrA (methyl coenzyme-M reductase) genes. For both groups, the number of gene copies per gram of DM rumen content was higher in the tropical site $(P<0.001)$. For cellulolytic bacteria, higher number of $r r s$ copies per gram of DM of rumen content were detected for Fibrobacter succinogenes in the temperate site $(P<0.001)$, whereas no differences were observed for Ruminococcus flavefaciens or Ruminococcus albus numbers between sites, breeds and forage type. Protozoa numbers determined by counting did not vary between sites, forages or breeds, but a site $\times$ forage interaction was observed $(P=0.01)$ : there were more protozoa and $R$. albus in tropical sites for tropical forages. Our results suggest that rumen microbiota was mainly influenced by environment (temperate $v s$ tropical) and that forage type (C3 vs C4) and breed had minor effects. However, an interaction between environment and forage type was observed for some variables.
\end{abstract}

(c) 2016 Elsevier B.V. All rights reserved.

\footnotetext{
Abbreviations: $\mathrm{CH}_{4}$, methane; VFA, volatile fatty acid; DM, dry matter; $\mathrm{H}_{2}$, hydrogen; $\mathrm{CO}_{2}$, carbon dioxide; $\mathrm{H}$, high; $\mathrm{L}$, low; NDF, neutral detergent fibre assayed without a heat-stable amylase and expressed inclusive of residual ash; ADF, acid detergent fibre expressed inclusive of residual ash; OM, organic matter; $\mathrm{NH}_{3}$, ammonia; PBS, phosphate buffer saline; DGGE, denaturing gradient gel electrophoresis; TAE, Tris-Acetate-EDTA; MFS, methylgreen formalin saline.

* Corresponding author at: INRA, VetAgro Sup, UMR1213 Herbivores, F-63122 Saint-Genès-Champanelle France.

E-mail addresses: moufida_r@yahoo.fr (M. Rira), michel.doreau@clermont.inra.fr (M. Doreau).

1 Present address: Ecole Nationale Supérieure de Biotechnologie, Ali Mendjli, BP E66, 25100 Constantine, Algeria.
} 


\section{Introduction}

Enteric methane $\left(\mathrm{CH}_{4}\right)$ from ruminants accounts for 39\% of livestock sector greenhouse gases emissions (Gerber et al., 2013). Several studies have tested different strategies for $\mathrm{CH}_{4}$ abatement in ruminants (Hristov et al., 2013; Martin et al., 2010). However, although ruminant diets are based on forage, there is scant information on the effect of forage type on methanogenesis. A meta-analysis (Archimède et al., 2011) showed that enteric $\mathrm{CH}_{4}$ production per kg of dry matter (DM) intake may be higher for ruminants fed tropical forages than for those fed temperate forages. These differences in $\mathrm{CH}_{4}$ production may be due to the constitutional variation in the chemical structure of tropical and temperate forages, which display C4 and C3 carbon fixation pathways, respectively. However, differences could also be due to the ambient environment or to animal breed. Experiments carried out with tropical forages have always been conducted in the tropics with breeds originating from and adapted to a tropical environment; likewise, experiments with temperate forages have been run in temperate areas with breeds originating from these areas.

In the rumen, $\mathrm{CH}_{4}$ production results from microbial fermentation of carbohydrates. The main end products of this fermentation are volatile fatty acids (VFA), hydrogen $\left(\mathrm{H}_{2}\right)$ and carbon dioxide $\left(\mathrm{CO}_{2}\right)$. A large diverse population of microorganisms drives this process, especially bacteria and protozoa. The $\mathrm{H}_{2}$ produced is mainly used by methanogenic archaea to reduce $\mathrm{CO}_{2}$ to $\mathrm{CH}_{4}$. The activity, diversity and concentration of microbes harboured in the rumen are influenced by diet, breed, and the environment (King et al., 2011). However, to our knowledge, the relationships linking these three factors and their relative importance have not been studied.

The aim of this experiment was to compare rumen fermentation variables and microbial community structures of two breeds of sheep (Texel vs Blackbelly) fed C3 and C4 forages (permanent grasslands of high and low quality) in a temperate and a tropical site. Special attention was paid to methanogens and hydrogen-producing protozoa, which are associated with methanogenesis increase. Total bacteria were also studied, with a focus on cellulolytic bacteria, which play an important role in cell wall degradation and so can favour $\mathrm{CH}_{4}$ production.

\section{Materials and methods}

\subsection{Animals, diet, management and experimental design}

The study was conducted in parallel in two research sites located in temperate and tropical areas. The temperate site was in Auvergne, France, at $45.70^{\circ}$ North latitude and $3.03^{\circ}$ West longitude. Where the animals were housed, the average daily temperature ranged between $11.2{ }^{\circ} \mathrm{C}$ and $15.9{ }^{\circ} \mathrm{C}$, and the average relative humidity ranged between $32 \%$ and $46 \%$ during the experiment. The tropical area was in the French West Indies at $16.16^{\circ}$ North latitude and $61.30^{\circ}$ West longitude. The average daily temperature ranged between $21.0^{\circ} \mathrm{C}$ and $25.0^{\circ} \mathrm{C}$ and the average relative humidity ranged between $83 \%$ and $88 \%$ during the experiment.

In each site, 4 Texel wethers (temperate origin) and 4 Blackbelly rams (tropical origin) were used in two $4 \times 4$ Latin square designs. Sheep were born in the site where the experiment took place. Sheep were 2 years old and were fitted with a rumen cannula. Their body weight was $60.2 \pm 1.5 \mathrm{~kg}$ for the Texel sheep and $51.3 \pm 4.3 \mathrm{~kg}$ for the Blackbelly sheep in the temperate site; and $44.7 \pm 0.7 \mathrm{~kg}$ for the Texel sheep and $44.4 \pm 2.1 \mathrm{~kg}$ for the Blackbelly sheep in the tropical site. Management of experimental animals followed the guidelines for animal research of the French Ministry of Agriculture and other applicable guidelines and regulations for animal experimentation in the European Union (European Commission, 2010).

In both sites, sheep were fed the same forage from permanent grasslands, one grown in the temperate area and one grown in the tropical area. For each forage, there were two maturity stages that determined forage quality, high (H) and low (L), so that a total of 4 forages were studied in each site. Temperate forage was a semi-mountain permanent grassland, first cycle, flowering stage harvested in late June (L), and second cycle harvested in late August (H), both from the same parcel. The tropical forage was permanent grassland rich in Dichanthium spp; regrowths of 36 days (H) and 91 days (L), harvested in October. Transport of forage from one site to the other was by ship. Chemical composition of forages is presented in Table 1.

Each experimental period lasted 4 weeks: 2 weeks for adaptation to the forage, 1 week for $\mathrm{CH}_{4}$ measurements, and 1 week for digestibility and rumen sampling. Detailed results on digestibility and $\mathrm{CH}_{4}$ enteric productions arising from this study have been reported in a preliminary communication (Archimède et al., 2013) and will be fully published in a second paper (Archimède et al., unpublished).

Table 1

Average dry matter content and chemical composition of experimental forages ${ }^{\mathrm{a}}$.

\begin{tabular}{lllll}
\hline & Temp H & Temp L & Trop H \\
\hline Dry matter, g/kg fresh matter ${ }^{\mathrm{b}}$ & 875 & 879 & 866 \\
Organic matter, g/kg dry matter & 878 & 926 & 912 \\
NDF, g/kg dry matter & 586 & 623 & 742 \\
ADF, g/kg dry matter & 410 & 370 & 470 \\
Crude protein, g/kg dry matter & 134 & 83 & 742 & 120 \\
\hline
\end{tabular}

${ }^{a}$ Temp $\mathrm{H}=$ temperate forage high quality, Temp $\mathrm{L}=$ temperate forage low quality, Trop $\mathrm{H}=$ tropical forage high quality, Trop $\mathrm{L}=$ tropical forage low quality.

${ }^{b}$ Dry matter content of forages was on average 1.3 percentage unit higher in temperate site than in tropical site. 
Sheep were fed ad libitum twice daily at 07:00 and 19:00 and were housed in a closed barn in the temperate site and in a semi-open barn in the tropical site. Animals were tied in boxes equipped for separation between urine and faeces in male sheep. They had free access to water and salt block at all times.

\subsection{Measurement of feed intake and digestibility, and rumen sampling}

Feed intake was measured by weighing daily offered and refused forages for 5 consecutive days. A 200-g sample of offered and refused forages was taken, and DM content was determined by oven-drying at $60{ }^{\circ} \mathrm{C}$ until constant weight. Digestibility coefficient was measured by total collection of faeces for 5 consecutive days. After weighing and mixing, 10\% of daily collection of faeces were taken every day, and DM content was determined by oven-drying at $60{ }^{\circ} \mathrm{C}$ until constant weight.

Approximately $250 \mathrm{~g}$ of whole rumen contents were collected through the cannula just before and $3 \mathrm{~h}$ after the morning feeding. A subsample of exactly $30 \mathrm{~g}$ was used for microbial analysis. The remaining subsample was strained through a polyester monofilament fabric $(250 \mu \mathrm{m}$ mesh size). The $\mathrm{pH}$ was promptly measured using a portable pH-meter (CG840, electrode $\mathrm{Ag} / \mathrm{AgCl}$, Schott Geräte, Hofheim, Germany).

\subsection{Fermentation characteristics analysis}

For VFA, $0.8 \mathrm{~mL}$ of rumen fluid filtrate was mixed with $0.5 \mathrm{~mL}$ of a solution containing $4 \mathrm{mg} / \mathrm{mL}(\mathrm{w} / \mathrm{v}) \mathrm{crotonic}$ acid and $20 \mathrm{mg} / \mathrm{mL}(\mathrm{w} / \mathrm{v})$ metaphosphoric acid in $0.5 \mathrm{~mol} / \mathrm{L} \mathrm{HCl}$, kept at $4{ }^{\circ} \mathrm{C}$ for $2 \mathrm{~h}$ and centrifuged $\left(16,500 \times g, 10 \mathrm{~min}, 4{ }^{\circ} \mathrm{C}\right)$. The supernatant was stored at $-20^{\circ} \mathrm{C}$ until analysis. Ruminal VFA were determined in the rumen liquid phase by gas chromatography (Ottenstein and Bartley, 1971). The gas chromatograph was a Hewlett Packard 5889 equipped with a Stabilwax DA ( $30 \mathrm{~m} \times 0.53 \mathrm{~mm}$ i.d.) column maintained at $125^{\circ} \mathrm{C}$. The carrier gas was $\mathrm{H}_{2}(34.6 \mathrm{~mL} / \mathrm{min})$. For ruminal ammonia $\left(\mathrm{NH}_{3}\right), 1 \mathrm{~mL}$ of liquid phase was added to $0.1 \mathrm{~mL}$ of $\mathrm{H}_{3} \mathrm{PO}_{4} 0.8 \mathrm{M}$ and frozen at $-20{ }^{\circ} \mathrm{C}$ until analysis. Ruminal ammonia was assayed by colorimetry using the phenol-hypochlorite method (Weatherburn, 1967).

\subsection{Microbial analysis}

Thirty grams of whole rumen contents was diluted with $15 \mathrm{~mL}$ of ice-cold phosphate buffer saline (PBS) pH 6.8 and homogenized in three 1 min cycles with 1 min intervals on ice, using a Polytron grinding mill (Kinematica GmbH, Steinhofhalde Switzerland). Approximately $0.5 \mathrm{~g}$ was transferred to a $2-\mathrm{mL}$ Eppendorf tube and stored at $-80^{\circ} \mathrm{C}$ until DNA extraction.

Total DNA was extracted from approximately $200 \mathrm{mg}$ of frozen rumen sample using the QIAamp DNA purification kit (Qiagen, Hilden, Germany) (Yu and Morrison, 2004). DNA concentration and quality were checked by the A260 and A280 absorbance ratio in a NanoQuant Plate on a spectrophotometer (Infinity, Tecan, Männedorf, Switzerland). The extracted DNA was diluted to $10 \mathrm{ng} / \mu \mathrm{L}$ and used as a template for PCR to amplify the rrs gene of total bacteria and the mcrA gene for methanogens. Primers used in this study are listed in Table 2 (Edwards et al., 2007; Muyzer et al., 1993). When PCR products were used for denaturing gradient gel electrophoresis (DGGE), forward primers included a GC clamp ( $\sim 40 \mathrm{nt}$ ). All PCR reactions were performed in a T100 Thermal Cycler (Bio-Rad Laboratories, Marnes-la-Coquette, France) (Popova et al., 2011; Sadet et al., 2007). PCR products were analyzed by electrophoresis on $20 \mathrm{~g} / \mathrm{L}$ agarose gel (w/v) to check their size and estimate their concentration using a Low DNA Mass Ladder (Invitrogen, Carlsbad, CA).

For DGGE analysis, the amount of PCR product loaded on gels was adjusted to $100 \mathrm{ng}$ for both bacterial rrs and methanogen $m c r A$ genes. Gels had a $6-8(\mathrm{w} / \mathrm{v})$ polyacrylamide gradient and a denaturant gradient of $30-55 \%$ for $r r s$ and $10 \%$ to $30 \%$ for $m c r A$. Electrophoresis was performed in $0.5 \times$ Tris-Acetate-EDTA(TAE) buffer(TAE Buffer $1 \times, 40 \mathrm{mmol} / \mathrm{L} \mathrm{Tris} \mathrm{base,} 40 \mathrm{mmol} / \mathrm{Lglacial}$ acetic acid, $1 \mathrm{mmol} / \mathrm{L}$ EDTA) at $200 \mathrm{~V}$ and $60^{\circ} \mathrm{C}$ for $5 \mathrm{~h}$. Gels were silver stained using a commercial kit (Bio-Rad Laboratories) and analyzed using GelCompar II (Applied Maths, Kortrijk, Belgium). The peak area of all bands ( $\mathrm{N})$ and of each band ( $\mathrm{n}_{\mathrm{i}}$ ) and the number of bands $\mathrm{S}$ were used to calculate the community biodiversity using three indices: the Shannon index (H) calculated as $H=-\Sigma\left(n_{i} / N\right)$. $\ln \left(n_{i} / N\right)$, Simpson's dominance index $(\lambda)$ calculated as $\lambda=\Sigma\left(n_{i} / N\right)^{2}$, and the evenness index $(e)$ calculated as e $=\mathrm{H} / \mathrm{ln} \mathrm{S}$ (Heip et al., 1998).

The quantitative (q) PCR for total bacteria (rrs gene) and methanogens (mcrA gene) was carried out (Morgavi et al., 2013). The slope and efficiency for $r r s$ and $m c r A$ primers were: -3.45 and $95.6 \%$, and -3.43 and $95.1 \%$, respectively, with $\mathrm{R}^{2}$ being greater than 0.99 in both cases. The cellulolytic bacteria Fibrobacter succinogenes, Ruminococcus flavefaciens, and Ruminococcus albus were quantified with primers targeting the rrs gene (Denman and McSweeney, 2006; Koike and Kobayashi, 2001). The slope and efficiency for each primer pair were, respectively, -3.19 and $105.8 \%,-3.52$ and $92.3 \%$, and -3.54 and $91.5 \%$. For each rumen content sample, results were expressed as the mean of three replicates in $\operatorname{rrs}$ or $m c r A \log _{10} \operatorname{copies}$ per gram of DM of rumen contents.

For protozoa counting, $3 \mathrm{~mL}$ of rumen fluid was added to $3 \mathrm{~mL}$ of methylgreen formalin saline (MFS) solution (35 mL/L formaldehyde, $0.14 \mathrm{mmol} / \mathrm{L} \mathrm{NaCl}, 0.92 \mathrm{mmol} / \mathrm{L}$ methylgreen) and stored in the dark at room temperature. Rumen fluid/MFS solutions were diluted in an equal volume of PBS before protozoa counts under a microscope $(\times 400)$ in a Neubauer chamber (Ranilla et al., 2007). Data were expressed as $\log _{10}$ cells $/ \mathrm{mL}$. 
Table 2

Oligonucleotides used as primers for PCR-DGGE and qPCR analysis.

\begin{tabular}{|c|c|c|c|c|c|}
\hline Oligonucleotides & Oligonucleotide sequences & Target & $\begin{array}{l}\text { Amplicon } \\
\text { length (bp) }\end{array}$ & Use in & Primer references \\
\hline $\begin{array}{l}534 \mathrm{R}- \\
341 \mathrm{f}-\mathrm{GC}\end{array}$ & $\begin{array}{l}\text { 5'-ATT ACC GCG GCT GCT GG } \\
5^{\prime}-(\text { GC)-CC TAC GGG AGG CAG CAG }\end{array}$ & rrs Bacteria & 193 & PCR-DGGE & Muyzer et al. (1993) \\
\hline $\begin{array}{l}\text { mcrAr } \\
\text { mcrAf-GC }\end{array}$ & $\begin{array}{l}\text { 5'-TTC ATT GCR TAG TTW GGR TAG TT } \\
\left.5^{\prime} \text {-(GC) }\right)_{40} \text {-GGT GGT GTM GGA TTC ACA } \\
\text { CAR TAY GCW ACA GC }\end{array}$ & mcrA Methanogens & $460-490$ & PCR-DGGE & Luton et al. (2002) \\
\hline $\begin{array}{l}\text { q } m c r A-\mathrm{R} \\
\mathrm{q} m c r A-\mathrm{F}\end{array}$ & $\begin{array}{l}\text { 5'-GBARGTCGWAWCCGTAGAATCC } \\
\text { 5'-TTCGGTGGATCDCARAGRGC }\end{array}$ & mcrA Methanogens & 140 & qPCR & Denman et al. (2007) \\
\hline $\begin{array}{l}799 \mathrm{R} 2 \\
520 \mathrm{~F}\end{array}$ & $\begin{array}{l}\text { 5'-AACAGGATTAGATACCCTG } \\
\text { 5'-AGCAGCCGCGGTAAT }\end{array}$ & rrs Bacteria & 280 & qPCR & Edwards et al. (2007) \\
\hline $\begin{array}{l}\text { FS586-f } \\
\text { FS706-r }\end{array}$ & $\begin{array}{l}\text { 5'-GTTCGGAATTACTGGGCGTAAA } \\
\text { 5'-CGCCTGCCCCTGAACTATC }\end{array}$ & rrs Fibrobacter succinogenes & 121 & qPCR & $\begin{array}{l}\text { Denman and } \\
\text { McSweeney (2006) }\end{array}$ \\
\hline $\begin{array}{l}\text { RF96-f } \\
\text { RF220-r }\end{array}$ & $\begin{array}{l}\text { 5'-CGAACGGAGATAATTTGAGTTTACTTAGG } \\
\text { 5'-CGGTCTCTGTATGTTATGAGGTATTACC }\end{array}$ & rss Ruminococcus flavefaciens & 132 & qPCR & $\begin{array}{l}\text { Denman and } \\
\text { McSweeney (2006) }\end{array}$ \\
\hline $\begin{array}{l}\text { RA1281f } \\
\text { RA1439r }\end{array}$ & $\begin{array}{l}5^{\prime}-\text {-CCC TAA AAG CAG TCT TAG TTC G } \\
5^{\prime} \text {-CCT CCT TGC GGT TAG AAC A }\end{array}$ & rrs Ruminococcus albus & 175 & qPCR & $\begin{array}{l}\text { Koike and Kobayashi } \\
\text { (2001) }\end{array}$ \\
\hline
\end{tabular}


Table 3

Dry matter (DM) intake and digestibility, and rumen fermentation criteria before feeding in Texel (T) and Blackbelly (B) sheep fed four forages in temperate and tropical site.

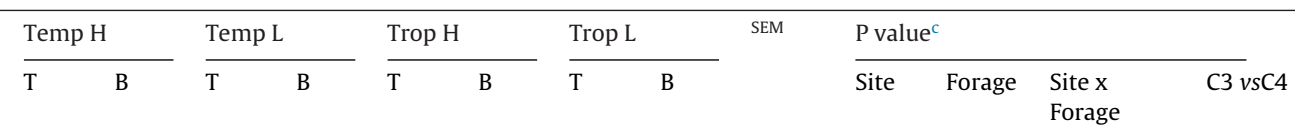

\begin{tabular}{|c|c|c|c|c|c|c|c|c|c|c|c|c|c|}
\hline \multicolumn{14}{|c|}{ DM intake, $\mathrm{g} / \mathrm{kg} \mathrm{BW}^{\mathrm{b}}$} \\
\hline Temperate site & 28.9 & 21.8 & 26.3 & 25.2 & 16.8 & 17.0 & 12.9 & 15.1 & \multirow[t]{2}{*}{1.87} & \multirow[t]{2}{*}{0.95} & \multirow[t]{2}{*}{$<0.001$} & \multirow[t]{2}{*}{0.17} & \multirow[t]{2}{*}{$<0.001$} \\
\hline Tropical site & 25.8 & 22.8 & 21.9 & 23.7 & 14.8 & 22.8 & 13.8 & 18.7 & & & & & \\
\hline \multicolumn{14}{|c|}{ DM digestibility coefficient } \\
\hline Temperate site & 0.622 & 0.668 & 0.554 & 0.564 & 0.618 & 0.625 & 0.476 & 0.514 & \multirow[t]{2}{*}{0.0209} & \multirow[t]{2}{*}{0.004} & \multirow[t]{2}{*}{$<0.001$} & \multirow[t]{2}{*}{0.02} & \multirow[t]{2}{*}{0.27} \\
\hline Tropical site & 0.637 & 0.652 & 0.542 & 0.576 & 0.666 & 0.662 & 0.604 & 0.555 & & & & & \\
\hline \multicolumn{14}{|l|}{$\mathrm{pH}$} \\
\hline Temperate site & 6.45 & 6.38 & 6.33 & 6.40 & 6.53 & 6.46 & 6.52 & 6.37 & \multirow[t]{2}{*}{0.107} & \multirow[t]{2}{*}{0.22} & \multirow[t]{2}{*}{0.73} & \multirow[t]{2}{*}{0.26} & \multirow[t]{2}{*}{0.56} \\
\hline Tropical site & 6.62 & 6.64 & 6.56 & 6.48 & 6.40 & 6.44 & 6.39 & 6.50 & & & & & \\
\hline \multicolumn{14}{|l|}{$\mathrm{VFA}^{\mathrm{b}}, \mathrm{mmol} / \mathrm{L}$} \\
\hline Temperate site & 92.7 & 90.5 & 87.5 & 91.0 & 73.1 & 73.8 & 93.0 & 94.4 & \multirow[t]{2}{*}{6.72} & \multirow{2}{*}{0.79} & \multirow[t]{2}{*}{0.02} & \multirow[t]{2}{*}{0.30} & \multirow[t]{2}{*}{0.05} \\
\hline Tropical site & 81.3 & 83.1 & 78.6 & 95.5 & 75.3 & 89.9 & 85.9 & 98.9 & & & & & \\
\hline \multicolumn{14}{|l|}{ Acetate, $\mathrm{mmol} / \mathrm{mol}$} \\
\hline Temperate site & 711 & 717 & 751 & 754 & 722 & 718 & 711 & 696 & \multirow[t]{2}{*}{12.5} & \multirow[t]{2}{*}{0.02} & $<0.001$ & 0.02 & 0.002 \\
\hline Tropical site & 743 & 748 & 734 & 734 & 747 & 741 & 723 & 716 & & & & & \\
\hline Propionate, $\mathrm{mmol} /$ & & & & & & & & & & & & & \\
\hline Temperate site & 192 & 177 & 174 & 173 & 185 & 187 & 200 & 187 & 8.8 & 0.02 & 0.07 & 0.16 & 0.11 \\
\hline Tropical site & 163 & 173 & 179 & 178 & 158 & 170 & 185 & 187 & & & & & \\
\hline Butyrate, $\mathrm{mmol} / \mathrm{m}$ & & & & & & & & & & & & & \\
\hline Temperate site & 76 & 80 & 60 & 60 & 79 & 83 & 101 & 97 & 8.0 & 0.13 & 0.002 & 0.08 & 0.01 \\
\hline Tropical site & 75 & 69 & 68 & 69 & 74 & 75 & 75 & 79 & & & & & \\
\hline Minor VFA ${ }^{\mathrm{b}}, \mathrm{mmol}^{-}$ & & & & & & & & & & & & & \\
\hline Temperate site & 20 & 25 & 13 & 11 & 14 & 12 & 16 & 20 & 3.10 & 0.65 & 0.30 & 0.01 & 0.06 \\
\hline Tropical site & 19 & 10 & 19 & 19 & 20 & 14 & 17 & 18 & & & & & \\
\hline Acetate:Propionat & & & & & & & & & & & & & \\
\hline Temperate site & 3.72 & 4.06 & 4.35 & 4.37 & 3.94 & 3.86 & 3.43 & 3.73 & 0.260 & 0.007 & 0.02 & 0.10 & 0.03 \\
\hline Tropical site & 4.58 & 4.42 & 4.24 & 4.18 & 4.78 & 4.40 & 3.96 & 3.85 & & & & & \\
\hline Ammonia, mmol/L & & & & & & & & & & & & & \\
\hline Temperate site & 4.56 & 8.12 & 6.17 & 8.42 & 3.89 & 4.17 & 4.43 & 6.41 & 1.590 & 0.30 & 0.28 & 0.36 & 0.69 \\
\hline Tropical site & 6.69 & 5.28 & 8.49 & 6.59 & 7.95 & 5.99 & 8.11 & 5.83 & & & & & \\
\hline
\end{tabular}

a Temp $\mathrm{H}=$ temperate forage, high quality, Temp $\mathrm{L}=$ temperate forage, low quality,Trop $\mathrm{H}=$ tropical forage, high quality, Trop $\mathrm{L}=$ tropical forage, low quality.

b BW: body weight. VFA: volatile fatty acids. Minor VFA are the sum of isobutyrate, valerate, isovalerate and caproate.

c Breed effect, breed $x$ site and breed $x$ forage interactions were not significant for all measured parameters.

\subsection{Statistical analysis}

To determine effects of site, breed and forage on feed intake, digestibility, $\mathrm{pH}$, VFA concentration and composition, $\mathrm{NH}_{3}$ concentration, protozoa numbers, gene copy numbers and diversity indices, data underwent analysis of variance using PROC MIXED (SAS, 2008). The model included site $(n=2)$, forage $(n=4)$, breed $(n=2)$, interactions between forage and site, forage and breed and breed and site as fixed effects and animal nested within breed as random effect. Differences between C3 and C4 forages were also analyzed using orthogonal contrasts. Effects were declared significant at $P<0.05$. Linear regressions were established between $\mathrm{CH}_{4}$ emission per $\mathrm{kg}$ DM and the different populations of microbes.

\section{Results}

\subsection{Feed intake, digestibility and ruminal fermentation characteristics}

Dry matter intake expressed in $\mathrm{g} / \mathrm{kg}$ BW did not vary between sites and was higher for C3 forages than for C4 forages. Dry matter digestibility differed between sites, and a site $\mathrm{x}$ forage interaction was observed, digestibility being higher in tropical site than in temperate site only for C4 forages. Dry matter digestibility differed between forages, but this difference was due to forage quality within C3 and within C4 forages, but did not vary between C3 and C4 forages. No effect of breed was observed on feed intake and digestibility. Ruminal $\mathrm{pH}$ and $\mathrm{NH}_{3}$ concentration did not vary between sites, breeds or forages, and interactions were not significant before (Table 3) or after feeding (Table S1). Total VFA molar concentration before feeding did not vary with site, but was higher with temperate forages than with tropical forages $(P<0.05)$. After feeding, VFA concentration was higher in the temperate site than in the tropical site $(P<0.05)$, and the difference between temperate and tropical forages remained. Before and after feeding, the proportion of acetate was higher for tropical forage in the temperate site and lower for temperate forage in the tropical site, and the proportion of propionate and butyrate was higher for sheep fed tropical forage in the temperate site and lower for tropical forage in the temperate site (Table 3 and Table S1). The acetate:propionate ratio was higher for C4 forages in the tropical site, particularly for $\mathrm{H}$ forage with an 
Protozoal population in Texel (T) and Blackbelly (B) sheep fed four forages in temperate and tropical site. ${ }^{\mathrm{a}}$

\begin{tabular}{|c|c|c|c|c|c|c|c|c|c|c|c|c|c|}
\hline & \multicolumn{2}{|c|}{ Temp H } & \multicolumn{2}{|c|}{ Temp L } & \multicolumn{2}{|c|}{ Trop H } & \multicolumn{2}{|c|}{ Trop L } & \multirow[t]{2}{*}{ SEM } & \multicolumn{4}{|c|}{$P$ value $^{\mathrm{c}}$} \\
\hline & $\mathrm{T}$ & B & $\mathrm{T}$ & B & $\mathrm{T}$ & B & $\mathrm{T}$ & B & & Site & Forage & $\begin{array}{l}\text { Site } \mathrm{x} \\
\text { Forage }\end{array}$ & $\mathrm{C} 3$ vs $\mathrm{C} 4$ \\
\hline \multicolumn{14}{|c|}{ Total, $\log _{10}$ cells $/ \mathrm{mL}$} \\
\hline Temperate site & 6.21 & 6.26 & 6.13 & 6.23 & 6.16 & 5.97 & 6.37 & 6.36 & \multirow[t]{2}{*}{0.109} & \multirow[t]{2}{*}{0.41} & \multirow[t]{2}{*}{0.62} & \multirow[t]{2}{*}{0.01} & \multirow[t]{2}{*}{0.50} \\
\hline Tropical site & 6.46 & 5.95 & 6.34 & 6.16 & 6.46 & 6.35 & 6.31 & 6.13 & & & & & \\
\hline \multicolumn{14}{|c|}{ Isotricha, $\log _{10}$ cells $/ \mathrm{mL}$} \\
\hline Temperate site & 5.16 & 4.69 & 2.68 & 2.74 & 4.35 & 3.46 & 5.27 & 3.92 & \multirow[t]{2}{*}{0.970} & \multirow[t]{2}{*}{0.77} & \multirow[t]{2}{*}{0.16} & \multirow[t]{2}{*}{0.41} & \multirow[t]{2}{*}{0.11} \\
\hline Tropical site & 4.11 & 3.03 & 4.25 & 2.48 & 4.70 & 4.00 & 5.23 & 3.16 & & & & & \\
\hline \multicolumn{14}{|c|}{ Dasytricha, $\log _{10}$ cells/mL } \\
\hline Temperate site & 5.59 & 5.25 & 5.08 & 3.53 & 5.56 & 5.44 & 5.94 & 5.49 & \multirow[t]{2}{*}{0.475} & \multirow[t]{2}{*}{0.35} & \multirow[t]{2}{*}{0.05} & \multirow[t]{2}{*}{0.14} & \multirow[t]{2}{*}{0.52} \\
\hline Tropical site & 4.82 & 4.37 & 5.33 & 4.54 & 5.43 & 5.46 & 4.70 & 5.43 & & & & & \\
\hline \multicolumn{14}{|c|}{ Large Entodiniomorphs $s^{\mathrm{b}}, \log _{10}$ cells $/ \mathrm{mL}$} \\
\hline Temperate site & 5.85 & 6.02 & 6.00 & 6.16 & 5.85 & 5.65 & 5.87 & 6.19 & \multirow[t]{2}{*}{0.138} & \multirow[t]{2}{*}{0.14} & \multirow[t]{2}{*}{0.67} & \multirow[t]{2}{*}{0.41} & \multirow[t]{2}{*}{0.30} \\
\hline Tropical site & 6.31 & 5.76 & 6.12 & 6.02 & 6.34 & 6.21 & 6.15 & 5.68 & & & & & \\
\hline \multicolumn{14}{|c|}{ Small Entodiniomorphs ${ }^{\mathrm{b}}, \log _{10}$ cells $/ \mathrm{mL}$} \\
\hline Temperate site & 5.47 & 5.34 & 5.04 & 5.05 & 5.04 & 4.87 & 5.54 & 5.35 & \multirow[t]{2}{*}{0.085} & \multirow[t]{2}{*}{0.01} & \multirow[t]{2}{*}{$<0.001$} & $<0.001$ & $<0.001$ \\
\hline Tropical site & 5.01 & 4.97 & 5.27 & 5.08 & 5.04 & 5.01 & 5.17 & 5.17 & & & & & \\
\hline
\end{tabular}

Table 5

Quantification of rumen bacteria and methanogens in Texel (T) and Blackbelly (B) sheep fed four forages in temperate and tropical site. ${ }^{\text {a }}$

\begin{tabular}{|c|c|c|c|c|c|c|c|c|c|c|c|c|c|}
\hline & \multicolumn{2}{|c|}{ Temp H } & \multicolumn{2}{|c|}{ Temp L } & \multicolumn{2}{|c|}{ Trop H } & \multicolumn{2}{|l|}{ Trop L } & \multirow[t]{2}{*}{ SEM } & \multicolumn{4}{|l|}{$P$ value $^{\mathrm{b}}$} \\
\hline & $\mathrm{T}$ & B & $\mathrm{T}$ & B & $\mathrm{T}$ & B & $\mathrm{T}$ & B & & Site & Forage & $\begin{array}{l}\text { Site } \mathrm{x} \\
\text { Forage }\end{array}$ & $\mathrm{C} 3$ vs $\mathrm{C} 4$ \\
\hline \multicolumn{14}{|c|}{ Total bacteria, $\log _{10}$ rrs copy number/g DM } \\
\hline Temperate site & 11.14 & 11.64 & 11.41 & 11.46 & 11.47 & 11.49 & 11.17 & 11.26 & 0.089 & $<0.001$ & 0.03 & 0.001 & 0.14 \\
\hline Tropical site & 11.59 & 11.51 & 11.80 & 11.61 & 11.74 & 11.71 & 11.65 & 11.62 & & & & & \\
\hline \multicolumn{14}{|c|}{ Fibrobacter succinogenes, $\log _{10}$ rrs copy number/g DM } \\
\hline Temperate site & 9.78 & 9.67 & 9.59 & 9.57 & 9.54 & 9.60 & 9.30 & 9.42 & 0.143 & $<0.001$ & 0.12 & 0.13 & 0.11 \\
\hline Tropical site & 9.00 & 9.06 & 9.41 & 9.23 & 9.27 & 9.13 & 9.03 & 9.10 & & & & & \\
\hline \multicolumn{14}{|c|}{ Ruminococcus albus, $\log _{10}$ rrs copy number/g DM } \\
\hline Temperate site & 8.76 & 8.76 & 7.43 & 8.19 & 7.81 & 8.33 & 7.67 & 7.86 & 0.302 & 0.99 & 0.40 & $<0.001$ & 0.92 \\
\hline Tropical site & 7.62 & 7.57 & 8.48 & 8.07 & 8.47 & 8.45 & 8.17 & 8.00 & & & & & \\
\hline \multicolumn{14}{|c|}{ Ruminococcus flavefaciens, $\log _{10}$ rrs copy number/g DM } \\
\hline Temperate site & 8.78 & 8.57 & 8.57 & 8.47 & 8.50 & 8.64 & 8.23 & 8.19 & 0.185 & 0.30 & 0.10 & 0.39 & 0.22 \\
\hline Tropical site & 8.63 & 8.48 & 8.77 & 8.58 & 8.68 & 8.72 & 8.49 & 8.54 & & & & & \\
\hline \multicolumn{14}{|c|}{ Total methanogens, $\log _{10}$ mcrA copy number/g DM } \\
\hline Temperate site & 8.93 & 8.92 & 8.80 & 8.91 & 8.89 & 8.83 & 8.65 & 8.71 & 0.072 & $<0.001$ & 0.03 & 0.01 & 0.30 \\
\hline Tropical site & 9.22 & 8.93 & 9.31 & 9.20 & 9.26 & 9.24 & 9.09 & 9.23 & & & & & \\
\hline
\end{tabular}

a Temp $\mathrm{H}=$ temperate forage, high quality; Temp $\mathrm{L}=$ temperate forage, low quality; Trop $\mathrm{H}=$ tropical forage, high quality. Trop $\mathrm{L}=$ tropical forage, low quality.

b Breed effect, breed $\mathrm{x}$ site and breed $\mathrm{x}$ forage interactions were not significant for all measured parameters.

interaction site $\times$ forage after feeding (Table S1). No effect of breed was shown for VFA concentration or pattern, except for total VFA molar concentration after feeding, where a breed $\times$ site interaction $(P<0.05)$ was found.

\subsection{Ruminal microbiota}

Protozoa numbers did not vary among sites, forages or breeds, but a site $\times$ forage interaction was observed: protozoa population was higher for C3 forage in the temperate site, and for C4 forage in the tropical site (Table 4). Small entodiniomorphs $(<100 \mu \mathrm{m})$ were more abundant in the temperate site and in sheep fed C3 than in those fed C4 $(P<0.05)$. Large entodiniomorphs $(>100 \mu \mathrm{m})$, Dasytricha and Isotricha were not different between sites, forages or breeds.

Results of qPCR quantification of the bacterial rrs and methanogen mcrA gene copies are summarized in Table 5. The concentration of bacterial rrs copies was higher in the tropical site $(P<0.05)$ and for $\mathrm{H}$ forages. The concentration of $F$. succinogenes rrs gene copies was higher in the temperate site $(P<0.05)$. The concentration of $R$. albus was influenced by neither site nor forage, but a forage $\times$ site interaction was observed: higher $r$ rs copies were detected in the temperate site for C3 forages, whereas in the tropical site higher rrs copies were observed for C4 forages. There was no difference in $R$. flavefaciens numbers between sites, breeds or forages. 

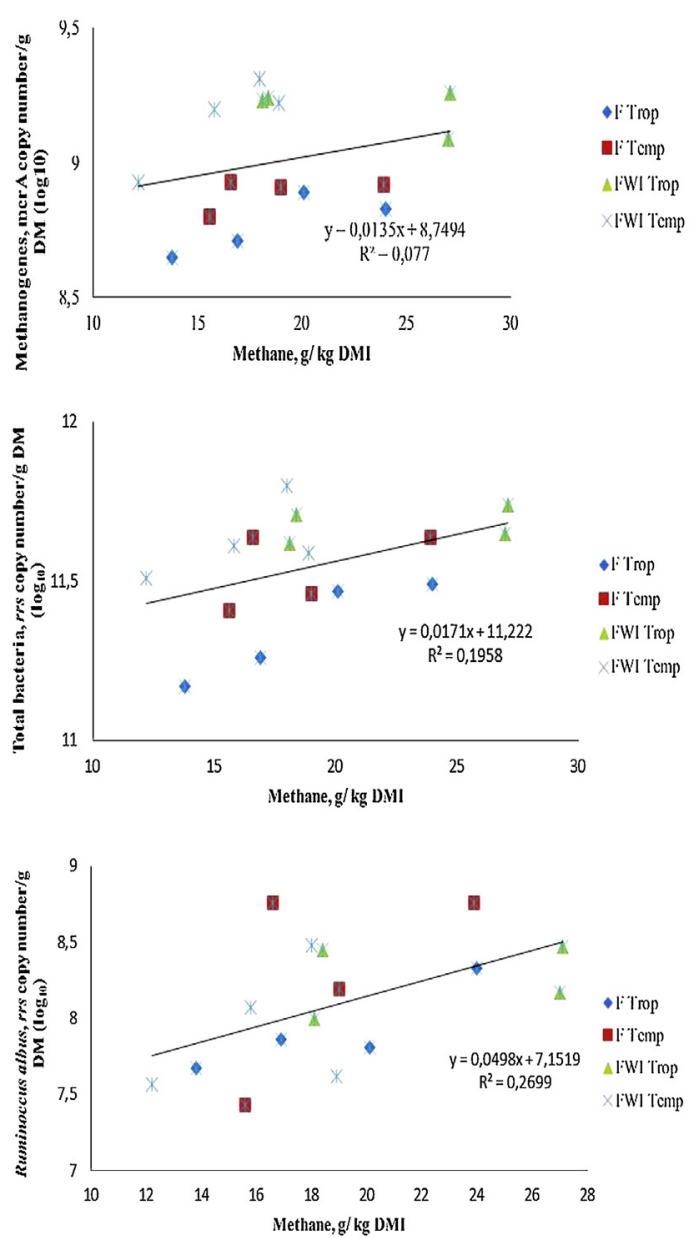
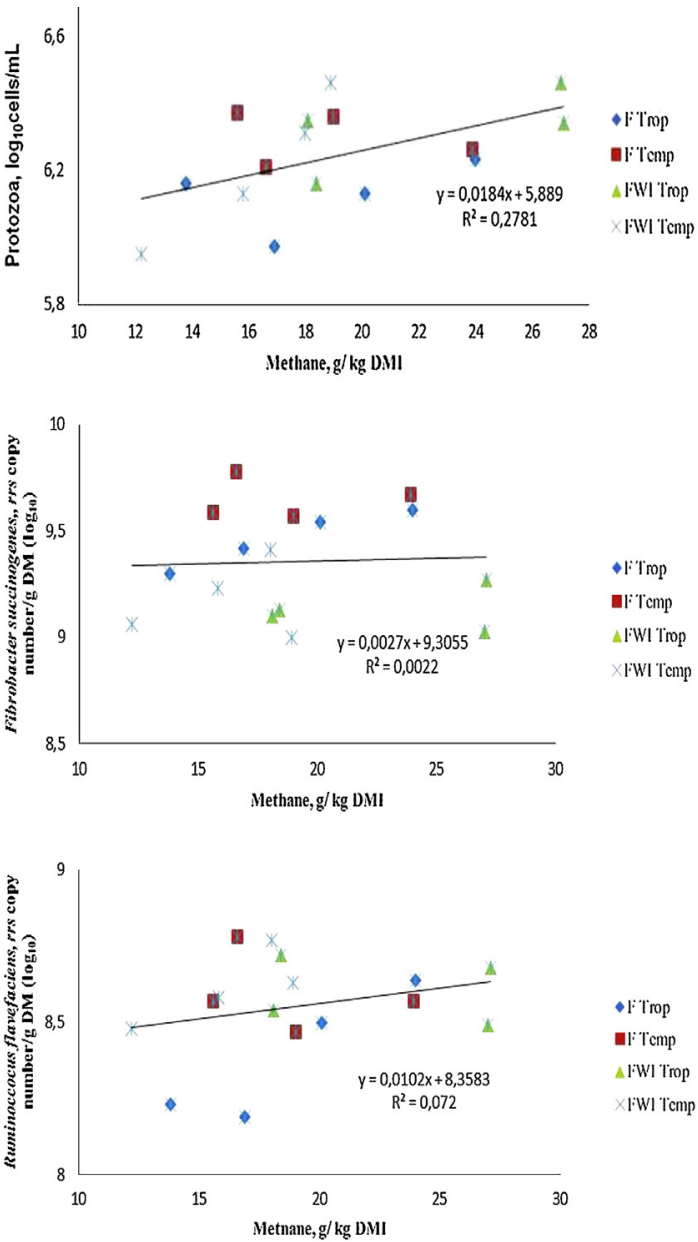

Fig. 1. Relationship between rumen microbes and methane enteric emission according to site (temperate (France, F) vs tropical (French West Indies, FWI)) and origin of forages (Temperate C3 (Temp) vs Tropical C4 (Trop)): high quality and low quality forage fed to Texel and Blackbelly. Each point is the mean of 4 individual values.

Methanogen concentration expressed as mcrA gene copy number in rumen contents was higher in the tropical site. Effects of forage and interaction between site and forage were observed: methanogen concentrations were higher in sheep fed C4 forages in the tropical site and in sheep fed C3 forages in the temperate site (Table 5).

DGGE analysis showed no difference within bacterial community structure and methanogenic community structure, and clustering patterns did not differ substantially among individual sheep (data not shown). Diversity indices were calculated from the rrs DNA PCR-DGGE profiles. Shannon, dominance and evenness indices did not vary between sites or breeds (Table S2). However, a tendential site $\times$ breed interaction was observed for the Shannon index in $r$ rs DNA PCR-DGGE profiles $(P=0.055)$. There was no difference between forages in either the number of bands or the values of diversity indices for the rrs DNA PCR-DGGE profiles (data not shown).

\subsection{Relationships between microbial populations and methane production}

Fig. 1 presents relationships between microbial abundances and $\mathrm{CH}_{4}$ production according to site, breed and forages (mean of 4 animals for each combination). Significant and positive relationships were found between protozoa population and $\mathrm{CH}_{4}$ production $(r=0.53, P<0.05)$, and between $R$. albus and $\mathrm{CH}_{4}$ production $(r=0.52, P<0.05)$ (Fig. 1$)$. No relationship was found between total bacteria, $R$. flavefaciens, $F$. succinogenes and $\mathrm{CH}_{4}$ production $(r=0.44,0.27$ and 0.05 , respectively, $P>0.05$ ). Higher $\mathrm{CH}_{4}$ production was associated with higher methanogens numbers but the relationship was non-significant $(r=0.28, P>0.05)$. Although some relationships were significant, coefficients of determination $\left(\mathrm{R}^{2}\right)$ were low. 


\section{Discussion}

Factors other than animal and feed characteristics are known to affect rumen digestion including, among other factors, climatic conditions (Decruyenaere et al., 2009). Digestion and $\mathrm{CH}_{4}$ production by ruminants differ between temperate and tropical conditions. However, as trials are usually carried out using feedstuffs harvested on site and a single, locally adapted breed (Archimède et al., 2011) it has not been possible to assess the relative importance of these factors. To our knowledge, our study is the first to simultaneously compare in a temperate and in a tropical environment, a temperate and a tropical sheep breed fed the same diet, allowing a finer interpretation of alleged differences between temperate and tropical sites in $\mathrm{CH}_{4}$ production, rumen fermentation, and microbial ecosystem. Results on intake and digestibility will be thoroughly discussed in a second paper (Archimède et al., unpublished) and are briefly discussed in this manuscript.

\subsection{Effect of environment on digestive processes}

Intake par kg BW was not affected by site. The temperature in the tropical site was certainly not high enough to affect intake as suggested by the review of Morand-Fehr and Doreau (2001). The higher digestibility observed in the tropical site is in accordance with the review of Morand-Fehr and Doreau (2001) for a wide range of temperatures, for a same intake. Independently of diet and animal type, there is limited experimental evidence to explain differences in rumen fermentation and methanogenesis between temperate and tropical sites. Such differences can result from differences in temperature or hygrometry. In this study, no difference in VFA concentration between sites was observed before feeding, but after feeding, the concentration was lower for the tropical site than for the temperate site. This may be explained by the difference in temperature, as it was reported by Kelley et al. (1967) in cows fed a constant diet at different controlled temperatures, and by Martz et al. (1990) in cows fed forage diets with moderate differences in intake. Another explanation could be the dilution of VFA in the rumen due to higher water consumption (Silanikove, 1992). However, in this experiment, rumen water content was $87.7 \%$ on average and was similar between sites, which does not support this hypothesis.

In contrast to our results, increase in total rumen VFA content and a decrease in pH were reported (Kadzere et al., 2002) when ambient temperature increased because VFA were absorbed less efficiently. In the present study, the tropical site had higher acetate proportion than the temperate site before and after feeding; the same tendency was observed for the acetate:propionate ratio. This result is in line with a previous study showing that high ambient temperature was associated with higher proportion of acetate (Kelley et al., 1967). However, this trend is not general, as another trial showed that an increase in temperature did not change VFA pattern in cattle, and increased propionate in sheep (Lippke, 1975).

The observed differences in VFA pattern can be due to differences in microbial communities between temperate and tropical sites, especially as there was no effect of site on daily feed intake, on average $20.5 \mathrm{~g} \mathrm{DM} / \mathrm{kg}$ body weight for both sites (Archimède et al., 2013). The qPCR analysis revealed that total bacteria and methanogen numbers were higher for the tropical site. Change in bacterial numbers may be partially explained by the lower concentration of small entodiniomorphs in the tropical site, and hence a decreased predatory activity on bacteria. In contrast to our results, a significant change in the composition but not in the concentration of microbial populations at elevated ambient temperature and humidity was reported (Tajima et al., 2007), this shift being accompanied by a decrease in concentration of VFA in the rumen. The targeted cellulolytic bacteria were not affected by site, except for $F$. succinogenes, which was more abundant in the temperate site (Table 5). This bacterium is a major fibre-degrading species in the rumen that does not produce $\mathrm{H}_{2}$ and is not associated with higher $\mathrm{CH}_{4}$ production (Chaucheyras-Durand et al., 2010). A higher acetate production is generally linked to higher $\mathrm{CH}_{4}$ production, but there was no site effect on $\mathrm{CH}_{4}$ production (Archimède et al., 2013) for this experiment (18.7 and $19.4 \mathrm{~g} / \mathrm{kg}$ DM intake on average for temperate and tropical sites, respectively). Methane was generally produced in higher quantities when $\mathrm{H}_{2}$-producing cellulolytic species such as Ruminococci were dominant, because of their association with methanogens, which consume $\mathrm{H}_{2}$ and produce $\mathrm{CH}_{4}$ (Chaucheyras-Durand et al., 2010; Morgavi et al., 2010) resulting simultaneously in higher production of acetate (Morgavi et al., 2010; Pavlostathis et al., 1990). This is in line with our results where the number of Ruminococci was also not affected by any of the factors tested and not correlated with $\mathrm{CH}_{4}$ production (Fig. 1).

In the present work we found little effect of environmental conditions on rumen fermentation and microbial populations. There are very few data in the literature: a change in rumen diversity and structure of microbiota was observed (RomeroPérez et al., 2011), suggesting that shifts in microbial populations may have been due to differences in temperature sensitivity among microbial species, but the range of temperature tested by these authors was between $-5^{\circ} \mathrm{C}$ and $-30^{\circ} \mathrm{C}$. The rumen and its contents are thermally stable but a modest change and disturbance within the rumen may occur with changes in ambient temperature. A difference in drinking water temperature can induce a difference in the temporary decrease in rumen temperature after drinking (Bewley et al., 2008). Another hypothesis is that a difference in ambient temperature (9 $v s .26^{\circ} \mathrm{C}$ ) results in a difference in mean retention time through hormonal changes, which may influence rumen fermentation (Barnett et al., 2015) and thus perhaps microbiota.

\subsection{Effect of forage type on digestive processes}

To date, studies on tropical forages have largely focused on comparisons of various plant species or physiological stages (Assoumaya, 2007). The higher intake of temperate forages compared to tropical ones was independent of site confirming the conclusion of the review of Assoumaya et al. (2007) comparing data on temperate forages carried out in temperate areas 
with data on tropical forages carried out in tropical areas. In the present experiment, it was observed a logical reduction in digestibility with poor quality forages but also a noticeable improvement in digestibility of lower quality C4 forages in the tropical site. In C4 forages, digestibility between high and low quality hay is severely reduced compared to C3 and animals on the tropical site seem better adapted to extract nutrients from this poor quality feed resource. The current study shows that grass physiological type (temperate C3 vs tropical C4) had more influence on rumen fermentation than site. Differences between forages in VFA concentration and pattern could be explained by their quality: nature and content of fibre and amount of lignin. In the present study, poor quality forages ( $\mathrm{H}$ vs $\mathrm{L}$ ) result in a lower VFA concentration and in a higher acetate:propionate ratio, independently of the site. This confirms literature data on tropical forages: a decrease in propionate relative to total VFA, while acetate increased with advancing maturity of the C4 grass Panicum maximum was observed (Assoumaya, 2007; Relling et al., 2001).There is no direct comparison between C3 and C4 grasses in the literature, so that it is difficult to know whether differences between C3 and C4 forages observed in this study derived from the chemical composition, such as the higher content of secondary metabolites of Dichanthium annulatum (Awad et al., 2015) present in the mixture of Dichanthium in this study. In a meta-analysis (Assoumaya et al., 2007), ruminal OM digestion, which is related to VFA production, was similar between tropical and temperate forages for the same fibre content, suggesting that chemical composition plays a major role in the differences found between tropical and temperate forages. In our experiment, butyrate proportion was higher for L than for $\mathrm{H}$ forages, and higher after feeding for temperate than for tropical forages. This suggests that butyrate production is not directly related to chemical composition. Butyrate is generally associated with protozoa (Eugène et al., 2004), but in our study there was no effect of forage type on numbers of protozoa, bacteria or methanogens. However, a significant site $\times$ forage interaction between temperate and tropical was found for total bacteria, R. albus, methanogens and protozoa. This shows that these populations were highest with tropical forages in the tropical site, suggesting that degradation of poor quality C4 forages characteristic of the tropics requires a denser microbial community. Forage type ( $\mathrm{C} 3$ vs $\mathrm{C} 4$ ) had no effect on the population numbers of total or cellulolytic bacteria and methanogens, whereas a global effect of forage is shown for both total bacteria and methanogens. This suggests an effect of quality, i.e. nutritive value of forages, on these populations. By contrast, a strong variation in ruminal bacteria of young steers fed either a $\mathrm{C} 3$ or a C4 grass was reported (Pitta et al., 2010).

No difference in methanogen mcrA copy number was detected among forages, although we expected to find more methanogens with tropical forages, because in this trial they generated more $\mathrm{CH}_{4}$ than temperate forages: 17.5 and $20.7 \mathrm{~g} / \mathrm{kg}$ DM intake on average for C3 temperate forages and C4 tropical forages, respectively (Archimède et al., 2013). These results are in line with previous results (Danielsson et al., 2012; Zhou et al., 2011) who reported that $\mathrm{CH}_{4}$ production was not related to total methanogen population. Methane production could be related to methanogen activity rather than their abundance (Popova et al., 2011).

\subsection{Effect of breed on digestive processes}

There is little information available on the extent to which rumen fermentation and microbes vary between sheep breeds. In our experiment two contrasting sheep breeds were chosen: one of temperate origin and the other of tropical origin. Overall, rumen fermentation and microbes were not affected by breed for any of the variables measured. The absence of change in ruminal VFA concentration between genotypes agrees with a previous comparison of two sheep breeds: a local one and an improved one (Ile-de-France and Churra-da-Terra-Quente) fed the same diet (Lourenço et al., 2013). Very few studies have compared more widely-contrasting breeds. A comparison between local Bos taurus breed and a Bos indicus breed in a tropical environment showed no differences in digestive processes (Grimaud and Doreau, 2003). Differences in digestion between breeds may differ more for poor quality feeds, for which local breeds should be better adapted than improved breeds (Lopez et al., 2001). However, breed $\times$ forage interaction was not significant in our study, and the absence of breed effect might be due to the adaptation of ruminal microbiota for both Texel and Blackbelly to the environment where the experiment took place, since they were born and raised close to each experimental site. The establishment of the rumen microbiota is influenced by nutritional and/or environmental exposure in young animals after birth. Consequently, induced variations in microbial populations colonizing the rumen can lead to modifications in fermentation and $\mathrm{CH}_{4}$ production (Abecia et al., 2013). The adaptation of Texel and Blackbelly microbiota to the temperate vs tropical environment may have reduced differences between breeds. In addition, climate conditions during this trial were not extreme enough to favor distinct adaptive and behavioral responses between breeds. Unfortunately, the origin and history of experimental animals is not specified in most studies. At the microbial level, qPCR analysis did not reveal any difference between Texel and Blackbelly. These results corroborate previous studies showing that methanogens, bacteria and protozoa population were not significantly different between two cattle breeds (Rooke et al., 2014). In contrast to this study, some authors have shown the impact of breed on potential $\mathrm{CH}_{4}$ production and rumen microbiota and suggest that the host animal exerts a controlling effect on its own gut microbiota (Danielsson et al., 2012; King et al., 2011).

Differences in microbial populations were predominantly attributable to diet, with the host being less influential. In addition to feed composition effects, the environment appears to influence the establishment and development of the rumen microbiota, leading the host to adapt so as to regulate the influence of diet and environment. 


\section{Conclusion}

This study shows that the differences observed in the rumen microbiota of sheep between tropical and temperate sites were intrinsic to the location and could not be attributed to local forages (temperate C3 vs tropical C4) or breeds. Total bacteria and methanogens were more abundant in the tropical site. This study also shows the adaptation capacity of each breed to its environment, suggested by the site $\times$ breed interaction. Future work should characterize the microbiota using high-throughput sequencing for phylogenetic and metagenomic analysis to gain a better understanding of the influence of the environment in shaping rumen populations.

\section{Conflict of interest}

The authors declare that there are not conflicts of interest.

\section{Acknowledgments}

This work has been granted by the French National Agency for Research (ANR) (EPAD project ANR-09-STRA-01), by Region Guadeloupe and other European funding: FEOGA, FEDER, FSE. We thank the staff of UE 1414 Herbipôle, INRA (France), especially Sébastien Alcouffe, André Guittard and Denis Roux, the staff of UE1284 PTEA, INRA (Guadeloupe) especially Fred Periacarpin for animal sampling, and Dominique Graviou for help in microbial analyses.

\section{Appendix A. Supplementary data}

Supplementary data associated with this article can be found, in the online version, at http://dx.doi.org/10.1016/j.anifeedsci.2016.08.010.

\section{References}

Abecia, L., Martín-García, A.I., Martínez, G., Newbold, C.J., Yáñez-Ruiz, D.R., 2013. Nutritional intervention in early life to manipulate rumen microbial colonization and methane output by kid goats postweaning. J. Anim. Sci. 91, 4832-4840.

Archimède, H., Eugène, M., Marie-Magdeleine, C., Boval, M., Martin, C., Morgavi, D.P., Lecomte, P., Doreau, M., 2011. Comparison of methane production between C3 and C4 grasses and legumes. Anim. Feed Sci. Technol. 166, 59-64.

Archimède, H., Rira, M., Eugène, M., Morgavi, D.P., Anaïs, C., Periacarpin, F., Calif, B., Martin, C., Marie-Magdeleine, C., Doreau, M., 2013. Intake, total-tract digestibility and methane emission of Texel and Blackbelly sheep fed C4 and C3 grasses tested simultaneously in a temperate and a tropical area. Adv. Anim. Biosci. 4, 285.

Assoumaya, C., Sauvant, D., Archimède, H., 2007. Etude comparative de l'ingestion et de la digestion des fourrages tropicaux et tempérés. INRA Prod. Anim. 20, 383-392.

Assoumaya, C., 2007. Etude Des Facteurs Limitant l'ingestion Chez Les Petits Ruminants Valorisant Des Fourrages Tropicaux. PhD Thesis, Agro. Paris Tech., Paris, France, 298 pp.

Awad, M.M., Ragab, E.A., Atef, A., 2015. Phytochemical investigation and biological evaluation of Dichanthium annulatum (Forrsk). J. Sci. Innov. Res. 4, $131-137$.

Barnett, M.C., McFarlane, J.R., Hegarty, R.S., 2015. Low ambient temperature elevates plasma triiodothyronine concentrations while reducing digesta mean retention time and methane yield in sheep. J. Anim. Physiol. Anim. Nutr. 99, 483-491.

Bewley, J.M., Grott, M.W., Einstein, M.E., Schutz, M.M., 2008. Impact of intake water temperatures on reticular temperatures of lactating dairy cows. J. Dairy Sci. 91, 3880-38837.

Chaucheyras-Durand, F., Masséglia, S., Fonty, G., Forano, E., 2010. Influence of the composition of the cellulolytic flora on the development of hydrogenotrophic microorganisms, hydrogen utilization, and methane production in the rumens of gnotobiotically reared lambs. Appl. Environ. Microbiol. 76, 7931-7937.

Danielsson, R., Schnürer, R., Arthurson, V., Bertilsson, J., 2012. Methanogenic population and CH4 production in swedish dairy cows fed different levels of forage. Appl. Environ. Microbiol. 78, 6172-6179.

Decruyenaere, V., Buldgen, A., Stilmant, D., 2009. Factors affecting intake by grazing ruminants and related quantification methods: a review. Biotechnol. Agron. Soc. Environ. 13, 559-573.

Denman, S.E., McSweeney, C.S., 2006. Development of a real-time PCR assay for monitoring anaerobic fungal and cellulolytic bacterial populations within the rumen. FEMS Microbiol. Ecol. 58, 572-582.

Denman, S.E., Tomkins, N.W., McSweeney, C.S., 2007. Quantitation and diversity analysis of ruminal methanogenic populations in response to the antimethanogenic compound bromochloromethane. FEMS Microbiol. Ecol. 62, 313-322.

Edwards, J.E., Huws, S.A., Kim, E.J., Kingston-Smith, A.H., 2007. Characterization of the dynamics of initial bacterial colonization of nonconserved forage in the bovine rumen. FEMS Microbiol. Ecol. 62, 323-335.

Eugène, M., Archimède, H., Michalet-Doreau, B., Fonty, G., 2004. Effects of defaunation on microbial activities in the rumen of rams consuming a mixed diet (fresh Digitaria decumbens grass and concentrate). Anim. Res. 53, 187-200.

European Commission, 2010. Directive 2010/63/EU of the European Parliament and of the Council of 22 September 2010 on the protection of animals used for scientific purposes. Off. J. Europ. Union, L 276/33-L 276-79. Available at: http://eur-lex.europa.eu/legal-content/EN/TXT/PDF/?uri=CELEX:32010L0063\&from=EN (accessed 12.06.16).

Gerber, P.J., Steinfeld, H., Henderson, B., Mottet, A., Opio, C., Dijkman, J., Falcucci, A., Tempio, G., 2013. Tackling Climate Change Through Livestock -A Global Assessment of Emissions and Mitigation Opportunities. Food and Agriculture Organization of the United Nations (FAO), Rome, Italy.

Grimaud, P., Doreau, M., 2003. Effects of level of intake and nitrogen supplementation on digestion by cows in a tropical environment. Anim. Res. 52, $103-118$.

Heip, C.H.R., Herman, P.M.J., Soetaert, K., 1998. Indices of diversity and evenness. Océanis 24, 61-87.

Hristov, A.N., Oh, J., Firkins, J.L., Dijkstra, J., Kebreab, E., Waghorn, G., Makkar, H.P.S., Adesogan, A.T., Yang, W., Lee, C., 2013. Mitigation of methane and nitrous oxide emissions from animal operations: I. A review of enteric methane mitigation options. J. Anim. Sci. 91, 5045-5069.

Kadzere, C.T., Murphy, M.R., Silanikove, N., Maltz, E., 2002. Heat stress in lactating dairy cows: a review. Livest. Prod. Sci. 77, 59-91. 
Kelley, R.O., Martz, F.A., Johnson, H.D., 1967. Effect of environmental temperature on ruminal volatile fatty acid levels with controlled feed intake. J. Dairy Sci. 50, 531-533.

King, E.E., Smith, R.P., St-Pierre, B., Wright, A.D.G., 2011. Differences in the rumen methanogen populations of lactating Jersey and Holstein dairy cows under the same diet regimen. Appl. Environ. Microbiol. 77, 5682-5687.

Koike, S., Kobayashi, Y., 2001. Development and use of competitive PCR assays for the rumen cellulolytic bacteria: Fibrobacter succinogenes, Ruminococcus albus and Ruminococcus flavefaciens. FEMS Microbiol. Lett. 204, 361-366.

Lippke, H., 1975. Digestibility and volatile fatty acids in steers and wethers at 21 and $32{ }^{\circ} \mathrm{C}$ ambient temperature. J. Dairy Sci. $58,1860-1864$.

Lopez, S., Frutos, P., Mantecon, A.R., Giraldez, F.J., 2001. Comparative digestion of herbage by two breeds of sheep: effects of grass maturity stage and level of intake. Anim. Sci. 73, 513-522.

Lourenço, A.L., Cone, J.W., Fontes, P., Dias-da-Silva, A.A., 2013. Effects of sheep breed and soybean meal supplementation on rumen environment and degradation kinetics. NJAS Wagen. J. Life Sci. 64-65, 77-85.

Luton, P.E., Wayne, J.M., Sharp, R.J., Riley, P.W., 2002. The mcrA gene as an alternative to 16S rRNA in the phylogenetic analysis of methanogen populations in landfill. Microbiology 148, 3521-3530.

Martin, C., Morgavi, D.P., Doreau, M., 2010. Methane mitigation in ruminants. From microbes to the farm scale. Animal 4, $351-365$.

Martz, F.A., Payne, C.P., Matches, A.G., Belyea, R.L., Warren, W.P., 1990. Forage intake, ruminal dry matter disappearance, and ruminal blood volatile fatty acids for steers in 18 and $32^{\circ} \mathrm{C}$ temperatures. J. Dairy Sci. 73, 1280-1287.

Morand-Fehr, P., Doreau, M., 2001. Alimentation des ruminants soumis à un stress de chaleur. INRA Prod. Anim. 14, 15-27.

Morgavi, D., Forano, E., Martin, C., Newbold, C.J., 2010. Microbial ecosystem and methanogenesis in ruminants. Animal 4, $1024-1036$.

Morgavi, D.P., Martin, C., Boudra, H., 2013. Fungal secondary metabolites from Monascus spp. reduce rumen methane production in vitro and in vivo. J. Anim. Sci. 91, 848-860.

Muyzer, G., De Waal, E.C., Uitterlinden, A.G., 1993. Profiling of complex microbial populations by denaturing gradient gel electrophoresis analysis of polymerase chain reaction-amplified genes coding for 16S rRNA. Appl. Environ. Microbiol. 59, 695-700.

Ottenstein, D.M., Bartley, D.A., 1971. Improved gas chromatography separation of free acids C2-C5 in dilute solution. Anal. Chem. $43,952-955$.

Pavlostathis, S.G., Miller, T.L., Wolin, M.J., 1990. Cellulose fermentation by continuous cultures of Ruminococcus albus and Methanobrevibacter smithii. Appl. Microbiol. Biotechnol. 33, 109-116.

Pitta, D.W., Pinchak, W.E., Dowd, S.E., Osterstock, J., Gontcharova, V., Youn, E., Dorton, K., Yoon, I., Min, B.R., Fulford, J.D., Wickersham, T.A., 2010. Rumen bacterial diversity dynamics associated with changing from bermudagrass hay to grazed winter wheat diets. Microb. Ecol. 59, $511-522$.

Popova, M., Martin, C., Eugène, M., Mialon, M.M., Doreau, M., Morgavi, D.P., 2011. Effect of fibre-and starch-rich finishing diets on methanogenic Archaea diversity and activity in the rumen of feedlot bulls. Anim. Feed Sci. Technol. 166-167, 113-121.

Ranilla, M.J., Jouany, J.P., Morgavi, D.P., 2007. Methane production and substrate degradation by rumen microbial communities containing single protozoal species in vitro. Lett. Appl. Microbiol. 45, 675-680.

Relling, E.A., Van Niekerk, W.A., Coertze, R.J., Rethman, N.F.G., 2001. An evaluation of Panicum maximum cv. Gatton. The influence of stage of maturity on diet selection, intake and rumen fermentation in sheep. S. Afr. J. Anim. Sci. 31, 85-92.

Romero-Pérez, G.A., Ominski, K.H., McAllister, T.A., Krause, D.O., 2011. Effect of environmental factors and influence of rumen and hindgut biogeography on bacterial communities in steers. Appl. Environ. Microbiol. 77, 258-268.

Rooke, J.A., Wallace, R.J., Duthie, C.A., McKain, N., de Souza, S.M., Hyslop, J.J., Ross, D.W., Waterhouse, T., Roehe, R., 2014. Hydrogen and methane emissions from beef cattle and their rumen microbial community vary with diet, time after feeding and genotype. Br. J. Nutr. $112,398-407$.

Statistical Analysis System, 2008. SAS/STAT 9.2 User's Guide. SAS Institute, Cary, NC.

Sadet, S., Martin, C., Meunier, B., Morgavi, D.P., 2007. PCR-DGGE analysis reveals a distinct diversity in the bacterial population attached to the rumen epithelium. Animal 1, 939-944.

Silanikove, N., 1992. Effects of water scarcity and hot environment on appetite and digestion in ruminants: a review. Livest. Prod. Sci. 30, $175-1794$.

Tajima, K., Nonaka, I., Higuchi, K., Takusari, N., Kurihara, M., Takenaka, A., Mitsumori, M., Kajikawa, H., Aminov, R.I., 2007. Influence of high temperature and humidity on rumen bacterial diversity in Holstein heifers. Anaerobe 13, 57-64.

Weatherburn, M.W., 1967. Phenol-hypochlorite reaction for determination of ammonia. Anal. Chem. 39, 971-974.

Yu, Z., Morrison, M., 2004. Improved extraction of PCR quality community DNA from digesta and fecal samples. Biotechniques 36, $808-813$.

Zhou, M., Chung, Y.H., Beauchemin, K.A., Holtshausen, L., Oba, M., McAllister, T.A., Guan, L.L., 2011. Relationship between rumen methanogens and methane production in dairy cows fed diets supplemented with a feed enzyme additive. J. Appl. Microbiol. 111, 1148-1158. 